\title{
Research on Determinants of Brand Loyalty of Consumer: Evidence from Organic Food Industry in Vietnam
}

\author{
Nguyen Cuong Nam* \\ School of Management, Vietnam Haiphong University \\ Haiphong - 180000, Haiphong, Vietnam. E-mail: 451417524@qq.com
}

Received 10 December 2019; accepted 22 January 2020

\begin{abstract}
The term "organic food" has become one of the fastest-growing consumption trends in the cuisine industry not only in the world but also in Vietnam. It is mainly due to the fact that brands currently play a range of significant roles in enhancement of consumers' lives and improvement of the company's financial value. Brands are significant for marketers in meeting the desirable and necessary needs of consumers through establishing and communicating brand stories. The paper is conducted with the approach from consumer for the purpose of estimating appropriate determinants influencing on brand loyalty of consumer in the context of Vietnamese economy, especially in organic food industry. After analyzing the data of 450 questionnaires with descriptive statistics, reliability statistics, correlation and regression analysis between both direct effects of independents variables to dependent variable by SPSS 20 software, it is evident that functional value, social value, emotional value price worthiness, brand trust and brand social responsibility image directly impact on brand loyalty of consumer.

More importantly, the author propose a range of efficient solutions as well as effective marketing strategies for Vietnamese enterprises to establish, maintain and promote the brand loyalty of customer based on the research results; especially focusing on enhancing the perceived values of consumer to the brand, building information communication channels distribution channel; and conducting the discount programs in some special occasions, which is an imperative issue in both theoretical and practical aspects.
\end{abstract}

Keywords: Brand loyalty; organic food in Vietnam; customer satisfaction; marketing; brand trust; customer involvement; customer loyalty.

\section{Introduction}

In terms of theory, Amine (1998) and many scholars who have conducted the researches on brand stated that brand loyalty leads to a range of significant impacts for the growth of enterprises or their brand. In fact, if consumers have the loyalty for the brand they are using, they will tend to protect the brand from unfavorable 


\section{Nguyen Cuong Nam}

information and encourage as well as introduce others to buy products of the brand. More importantly, the customer will this brand many times and refuse to buy the products of competitive brands.

In practical terms, it is evident to note that companies always focus on paying attention and special care to the group of loyal customers and their satisfaction to the brand as well as the services of the company. Maintaining a huge number of loyal customers brings many benefits for enterprises, including maintaining stably sale volume and revenue of the company, reducing business expenses, protecting brand and the negligence or error of enterprises would be more accepted and ignored.Thses are the reasons why currently there have been many both theoretical and practical researches on effective solutions to build and maintain the customer's loyalty.

However, there are a range of changes in the loyalty of customer in the recent situation. Customer is increasingly wise and their expectation is much more than before. The changes of values, standards and behaviors of the future generations have made customer require more choices in brand of a product. In fact, the competition in the market has been increasingly drastic as well as the influences of advertising programs, sale promotional campaigns as well as the Internet development, customers just need to click to search the products or services that meet their need with an affordable price and high quality in a short time. As a result, it is harder for the enterprises to create unique differences compared with other competitive brands. This leads to the difficulties in maintaining the stability of brand loyalty. Therefore, the enterprises need to come up with solutions to maintain the stable numbers of customer who is loyal with their brand in the context of current economy.

In Vietnam, the economy has been officially run according to the market structure since 1986 (beginning of innovation period). Thus, the acceptance, researching, especially applying the theories and establishment of brand loyalty have been conducted slowly and done in the terms of summarizing the theories and results of the foreign researches and the practical experiences (Dinh, 2010; Do, 2006; Luc, 2010; Nguyen, 2011; Vu, 2007). They indicate that the exploration, establishing the concept model and examination of theories to conduct the practical researches are limited. At the same time, the concern in brand value makes them ignore that the brand loyalty is a part of brand value and its importance in it.

For many authors in the world, brand loyalty is a topic that they spend too much time and afford on researching. Some authors partly proposed a range of definition to determine what the brand loyalty is (Dick, 1994; Funk, 2001; Jacoby, 1978; Oliver, 1999). There are some other authors classifying the brand loyalty into many different kinds (Aaker, 1991; Assel, 1992; Brown, 1952; Gounaris, 2004; Rundle-Thiele,2001). Thanks to this, it is clear to identify the characters and behaviors of each respective group of customesr. Some authors conducted researches to explore and designate the measurement of brand loyalty, establish the concept model of factors influencing on brand loyalty and examine the theory to prepare for conducting the practical researches (Bennett, 2002; Hunter, 1998; Kim et al, 2008; Punniyamoorthy, 2007; Uncles, 2003).

In these researches, some researches focus on the content of customer loyalty; some others tend to propose solutions to measure the brand loyalty; there are just 


\section{Research on Determinants of Brand Loyalty of Consumer: Evidence from Organic}

Food Industry in Vietnam

some researches concentrating on defining the factors impacting on brand loyalty and establishing the concept models which illustrate the relationship among these factors and the brand loyalty. However, the approach of brand loyalty of these researches is seen as a single dependent variable while it can be an aggregate dependent variable including many aspects (For example: Brand loyalty and behavior loyalty). In addition, the factors of previous models need to estimate and conduct the research in the context of Vietnamese economy to eliminate unnecessary factors and add more appropriate factors.

Therefore, our paper, based on the organic food industry in Vietnami, is conducted with the approach from consumer to gain scientific base, supporting Vietnamese enterprises to establish and promote the brand loyalty of customer, which is an imperative issue in both theoretical and practical aspects.

Our research had made some contributions. Firstly, the thesis built and tested the models of factors affecting the brand loyalty on organic food of Vietnam consumers. Secondly, the thesis built the system of scales for brand loyalty and factors affecting brand loyalty in the context of Vietnam for the organic food industry.Thirdly, There are some innovative controlling variables in concept model of the thesis that supports to find out who will be the potential consumer and has a high level of brand loyalty behavior of organic food industry in Vietnam

\section{Literature review}

According to Sekar (2009), names of the brand bring a range of symbolic meanings which directly impact on the decision-making process of the consumers. The American Marketing Association defines a brand as "a name, term, sign, symbol, or design, or a combination of them, intended to identify the goods or services of one seller or group of sellers and to differentiate them from those of competitors." The brand is seen as a protection method for both the customer, especially loyal customers and the producer. It defends them from competitors who deliver products that appear to be identical. Therefore, branding has been significant as it is the only way for the customer to recognize among the great number of similar products, including functional, rational, or tangible-related to product performance of the brand. They may also be more symbolic, emotional, or intangible-related to what the brand represents or means in a more abstract sense (Kotler and Keller, 2012)

Loyalty is a significant concept in marketing strategy. According to Uncles and Dowling (1998), customers do not have too many reasons to seek information about the other alternative brands when they are loyal to the brand. In fact, loyalty is an extremely famous concept among researchers in many disciplines because of its important marketing implications. Loyalty also makes buying decisions simpler and even become a habit. Having a huge number of loyal customers supports enterprises to create their competitive advantages because this customer group will bring many benefits for the companies such as maintaining and developing and reducing costs

Facts indicate that brand loyalty has been used in a business context to explain the repetitive buying models of consumer of the same brand or product as well as service category. According to Aaker (1991) brand loyalty is a premise to the firm's competitiveness and profitability. Other scholars have stated that brand loyalty is a very significant strategy of gaining the strongest competitive advantage while others 


\section{Nguyen Cuong Nam}

have argued that brand loyalty is at the center of the marketing activities of enterprises and it is seen as a key to approach marketing. According to Reichheld and Teal (1996), almost all the marketing strategies are directly and indirectly related to brand loyalty, which proved the significance of the researches on brand loyalty in the development of a company's marketing activities.

Several researches are proved that brand loyalty is witnessed as a result of its significant role for not only the businesses but also the consumers. Different authors have conceptualized brand loyalty in different ways. According to Jacoby (1978), brand loyalty is a kind of behavior response of the customers in their buying decision-making process, relating to psychological processes and emotional response. While, Jacoby and Chesnut (1978), suggested that brand loyalty "is a biased (non-random) behavioral response (purchase), expressed over time from a decision-making unit, considering one or more alternative brands and is a function of psychological processes (decision making, evaluative)".

Due to the fact that there are many changes in the conceptualization, the growth and the analysis of the construct of the researches on brand loyalty of the consumers there is a range of different dimensions of brand loyalty and each research will have the different result of classifying kinds of brand loyaty.

In terms of a behavioral view, brand loyalty of consumer is conceptualized as patronage, the frequency that a consumer buys the same product or service in a specific category compared with the total number of purchases that category by all the buyers, as Rundle-Thiele and Bennett (2001) stated.in terms of a attitudinal view, brand loyalty has been defined as an attitude, preference, intention to buy as Zeithaml et al. (1996) stated.Many researches showed that the attitudinal dimension gives and explains the reasons why consumers patronize a product or a service, including these significant factors: preference, a positive attitude over time and a psychological commitment. The usage of both behavioral and attitudinal elements of consumers' brand loyalty was first come up with by Day (1969) and since then a range of other researches have proposed the usage of behavioral and attitudinal components in the conceptualization of brand loyalty as Baloglu (2002); Day, (1969); Dick and Basu, (1994); Jones and Taylor, (2007) stated;Many researchers such as Jones and Taylor (2007) or Russell-Bennet et al. (2009) and Oliver (1999) proposed a conclusion that the combination of the behavioral and attitudinal loyalty is a more appropriate and reliable method in measuring the loyalty level of consumers. because neither behavioral loyalty nor attitudinal loyalty may not establish and analyze thoroughly the construct of the brand loyalty's concept model as Baloglu (2002) showed.

In its earliest days, loyalty was proposed as a uni-dimensional construct, which was related to the measurement perspective taken by the researcher. Two separate loyalty concepts evolved, namely, "brand preference" (Guest, 1944; Guest, 1955), which was later referred to as attitudinal loyalty and "share of market" (Cunningham, 1956), which was later referred to as behavioral loyalty. Based on the market changes, many researchers have recently introduced a number of new concept models to show the factors influencing on brand loyalty of the consumer in the current context. However, the relevance of these models when being applied for the organic food sector remains some certain limitations. 
Research on Determinants of Brand Loyalty of Consumer: Evidence from Organic Food Industry in Vietnam

In concept model of Gounaris and Stathakopoulos (2004) the types of brand loyalty that two scholars mentioned focus on the behavioral loyalty group. Therefore, Gounaris and Stathakopoulos ignored the loyal component of the customer's attitude. As a result, these types of brand loyalty in the model do not fully reflect the necessary components of true brand loyalty.

The concept model of Back and Parks (2004) is conducted based on the changes of attitude (perception - influence - intention) given by Oliver (1997). According to this, Oliver stated that consumers could become "loyal" to perception first, then emotional and intention and ultimately, behavior. however, this concept model is not appropriate with the products which have a low involvement. For products with a high involvement level, the customers need to identify and handle key information such as product functions, brands, and prices before forming attitudes towards products and brand.

\section{Research hypothesis}

Previous empirical researches have found the significant evidences of a positive relationship between functional value which is perceived by consumer and their brand loyalty. Studies reported that a brand which promotes high functional value attracts more the consumers' attention. According to Caruana and Fenech (2005), hedonic, profit oriented value; creative achievement and, functional value all have positive influence on brand loyalty. This relationship has been confirmed in the researches of Lin et al. (2006), Amine (1998), and Asshidin et al. (2016). In fact, the utility derived from the product quality and expected functions towards the product of consumer is called as functional value. Functional value was seen to be one of the most key impacting on consumer's purchasing intention. It is also evident that functional value was created by attributes such as reliability, durability. Hence, the first hypothesis of the research is noted as:

H1: There is a positive relationship between functional value and brand loyalty.

According to Bennett and Thiele (2002), and Collier \& Barnes (2015), the significance of emotion value in customer loyalty was found. They confirmed that emotions are very close to brand loyalty because emotional loyalty is one of elements of view loyalty (Caruana and Fenech 2005). Besides, the relationship between emotional value and brand loyalty was also confirmed in Yeh et al. research (2016). Additionally, the utility derived from the feelings or affective states that a product generates is called emotional value. In a conclusion, emotions play a part in every purchase decision.

$\mathrm{H} 2$ : There is a positive relationship between emotional value and brand loyalty.

In Huynh (2018) 's research, consumers may consider that purchasing organic products as a sign high social situation. When consumers perceived high social value from a product or brand, they will show their loyalty behaviors toward brand or product like publishing positive information and accepting more prices (Punniyamoorthy and Raj, 2007), Yeh et al. (2016) also confirmed this relationship. Fact indicated that the utility derived from the product's capability to promote social self-concept of consumer.

H3: There is a positive relationship between social value and brand loyalty. 


\section{Nguyen Cuong Nam}

Price is the consideration in terms of money for the products and services. In this regard, price is the most significant consideration. Furthermore, price importantly impacts on consumer's purchasing intention as price discount plays a significant role in motivating the consumer to switch brands as it is considered as one of the strongest antecedents of loyalty (Ryan et al., 1999). However, it is dificult to change the purchasing intention of consumers due to the brand loyalty. In addition, it is commonly observers that loyal customers inclined towards premium pricing and are less price sensitive. The utility derived from the product due to the reduction of its perceived costs.

H4: There is a positive relationship between price worthiness and brand loyalty.

The relationship between loyalty and brand trust has been explained by Garbarino and Johnson (amongst other authors) in their work. They highlighted the importance of trust in developing positive and favorable attitudes. Brand trust is the central construct for any long-term relationship. So, in the consumer-brand domain it may be an important contributor to the kind of emotional commitment that leads to long-term loyalty. So, it seems reasonable to expect that the higher the feeling of trust in a brand, the more the consumers are loyal to it.

H5: There is a positive relationship between brand trust and brand loyalty.

There are few studies, especially research of T. Weiwei (2007) addressing the relationship of brand social responsibility image and brand loyalty from consumers' perspective concluding that there is a positive relationship between brand social responsibility image and brand loyalty. However, scarce evidence has been found of the direct relationship of brand social responsibility image and customer satisfaction and brand loyalty (Poolthong and Mandhachitara, 2001)

H6: There is a positive relationship between brand social responsibility and brand loyalty.

\section{Research methods}

\subsection{Collecting the data}

In order to achieve the size of the sample according to the defined structure after eliminating the samples that are lack of information or low quality, the author decided to use 351/450 questionnaires for data analysis. The author conducted two kinds of survey to collect the data: Online survey and offline survey.

(1) Online survey: The author sent the questionnaire on some social media, such as on Facebook which is the most popular social media in Vietnam, especially on Facebook fanpages; or public or private Facebook groups of people who follow the scientific diet or healthy meals or people who are keen on organic food or using organic products. As a good result, the author collected 153/450 respondents, accounting $34 \%$ of the total.

(2) Offline survey: The data was collected by spreading the questionnaires in organic stores located in main districts of some big cities such as Haiphong City, Hanoi City and Ho Chi Minh City. As well as this, the author also conducted the survey in big supermarket systems such as BigC supermarket, Vinmart convenience stores system.

Firstly, based on the questionnaires and research results of previous researches relating to topic "brand loyalty of consumer" such as Ahmed I. Moolla and Christo 
Research on Determinants of Brand Loyalty of Consumer: Evidence from Organic Food Industry in Vietnam

A. Bisschoff (2012), the author collected threecontrolling variables,specifically gender,age and education, to analyze the profile of consumers who have intention of purchasing organic products and using them for a long time, which helps the author analyze and summarize who will be the potential and loyal consumer of organic products in Vietnamese market by researching on their gender; age; education; occupation; relationship status; monthly income.

More importantly, the author also added some innovative controlling variables, including "going to gym", "having kids"; and "visiting organic farm" because organic products are better for the heath of consumer, especially for people who keep fit or go to gym every day; good for children' comprehensively health development. Besides, visiting organic farm is also an innovative controlling variable because it shows the experiences and awareness of consumer about benefits of organic products as well as the social responsibility of organic companies. These variables supported clearly for the research to explore the potential customers who have high intention to buy and use organic products as well as be loyal with organic products in Vietnamese market. The results are shoued in table 1.

Table 1: Sample basic information $(N=351)$

\begin{tabular}{llcc}
\hline $\begin{array}{c}\text { Sample } \\
\text { characteristics }\end{array}$ & \multicolumn{1}{c}{$\begin{array}{c}\text { Characteristics } \\
\text { distribution }\end{array}$} & Amount & Percent (\%) \\
\hline Gender & male & 113 & 32.2 \\
& famale & 238 & 67.8 \\
Age & $18-22$ & 8 & 2.3 \\
& $23-26$ & 169 & 48.1 \\
& $27-40$ & 144 & 41.1 \\
& $41-50$ & 20 & 5.7 \\
Education & $>50$ & 10 & 2.8 \\
& Nof for high school & 6 & 1.7 \\
& For high school & 18 & 5.7 \\
& Technical school/college & 103 & 29.3 \\
Going to the gym & University & 203 & 57.8 \\
\multirow{4}{*}{ Having kids } & Undergraduate & 21 & 6.0 \\
& Yes & 251 & 71.5 \\
Visiting organic farm & No & 100 & 28.5 \\
& Yes & 208 & 59.3 \\
& No & 143 & 40.7 \\
& Yes & 214 & 61.0 \\
& No & 137 & 39.0 \\
\hline
\end{tabular}

\subsection{Variables measurement}

Independent variables: According to Punniyamoorthy and Raj (2007), perceived value is described as the consumer 's overall assessment of the utility of a product based on perceptions of what is received and what is given. In fact, perceived value is made up of several factors, including four most common factors identified that represents perceived value are: functional value, emotional value, social value and 


\section{Nguyen Cuong Nam}

price - worthiness, whose measure methods are designed based on previous reseachers' works (Quester and Lim, 2003; Knox and Walker, 2001; Olson, 2008; Punniyamoorthy and Raj, 2007; Petromilli, 2002). According to Garbarino and Johnson (1999), there is a positive relationship between brand loyalty and brand trust. The authors found that there is a distinct need of trust in promoting positive and favorable attitudes towards brands. Thus, brand trust is one of the most important constructs for any long-term relationship and seen as a significant contributor in attaching a kind of emotional commitment, which leads to a long-term loyalty of consumer. This measure method is designed based on researches of Reast (2005) and Raimondo (2000). In fact, brand social responsibility is described as the consumers' perceptions about the brand's effort in supporting its community. Consequently, brand social responsibility image can be defined as, "Perception in the awareness of the consumers towards the brand they have used is beneficial for society, especially environment and community health, this measure method is designed based on researches of Kim et al. (2008), Fullerton (2005) and Foxall (2002).

Dependent variable: In fact, brand loyalty involves an ongoing commitment on the part of the consumerr with relating to awareness, feelings and behavioral react to a product category. Involvement is an unobserved state of motivation, arousal or interest toward a product. this measure method is designed based on researches of Moolla and Bisschoff (2012).

\subsection{Reliablity and validity}

The author used a confirmatory factor analysis to test the validity of the constructs, as shown in tables below. The reliability of each construct is measured by using the Cronbach's Alpha. After analysis and rejected the variable that is not suitable for the standard of reliability statistics, the table 5.10 shows the results of Cronbach's Alpha coefficients for nine factors. The results show that all constructs have higher scores than that of the acceptable level of Cronbach's Alpha 0.7. All the scale items are statistically significant at the significance level of 0.05 . Therefore, the data of this research have good convergent validity.

More importantly, with the rotated component matrix, 25 variables were rotated using the Varimax rotation with Kaiser Normalization. The results displayed by Table 2 indicated that all 25 variables loaded onto nine factors loading coefficients greater than 0.5 and there was no cross-loading on any factor.

Table 2: Reliablity and validity

\begin{tabular}{cccc}
\hline Variables & Measures & Correlation & $\begin{array}{c}\text { Cronbach } \\
\text { Alpha }\end{array}$ \\
\hline Functional Value (FV) & FV1 & 0.616 & 0.801 \\
& FV2 & 0.640 & \\
Social Value (SV) & FV3 & 0.684 & \\
& SV1 & 0.638 & 0.797 \\
Emotional Value (EV) & SV2 & 0.652 & \\
& EV3 & 0.631 & 0.773 \\
& EV2 & 0.772 & \\
& EV3 & 0.826 & \\
& & 0.803 &
\end{tabular}




\begin{tabular}{cccc}
\multirow{5}{*}{$\begin{array}{c}\text { Research on Determinants of Brand Loyalty of Consumer: Evidence from Organic } \\
\text { Food Industry in Vietnam }\end{array}$} \\
Price Worthiness (PW) & PW1 & 0.811 & 0.824 \\
& PW2 & 0.806 & \\
Brand Trust (BT) & PW3 & 0.817 & 0.852 \\
& BT1 & 0.764 & \\
Brand Social & BT2 & 0.804 & 0.814 \\
Responsibility Image & BT3 & 0.781 & \\
(BSRI) & BSRI & 0.817 & \\
Customer Satisfaction & BSR2 & 0.805 & \\
(CS) & CSR1 & 0.780 & \\
& CS2 & 0.803 & \\
Brand Loyalty (BL) & CS3 & 0.762 & \\
& CS4 & 0.745 & \\
& BL1 & 0.822 & \\
& BL2 & 0.777 & \\
& BL3 & 0.716 & \\
& & 0.801 & \\
\hline
\end{tabular}

\section{Empirical analysis and results}

\subsection{Descriptive statistics}

The table 3 shows the results of Pearson correlations of all the variables. According to this, the Sig. value of all independent variables FV, SV, EV, PW, BT, BSRI and the dependent variable BL in Pearson correlations are all $0.000<0.05$. Hence, the linear is significant between observed variables and dependent variables.

Specifically, the correlation between BT (Brand Trust) and BL (Brand Loyalty) is highest with $\mathrm{r}=0.508$, following by $\mathrm{FV}, \mathrm{CS}$ and $\mathrm{CI}$ with $\mathrm{r}=0.463 ; 0.442$ and 0.431 while the correlation between $\mathrm{BL}$ and $\mathrm{EV}$ is lowest with $\mathrm{r}=0.328$

Table 3: Correlations result

\begin{tabular}{lcccccc}
\hline & FV & SV & EV & PW & BT & BSRI \\
\hline SV & $0.251^{* *}$ & & & & & \\
EV & $0.152^{* *}$ & $0.213^{* *}$ & & & & \\
PW & $0.329^{* *}$ & $0.273^{* *}$ & $0.259^{* *}$ & & & \\
BT & $0.442^{* *}$ & $0.373^{* *}$ & $0.217^{* *}$ & $0.324^{* *}$ & & \\
BSRI & $0.268^{* *}$ & $0.295^{*}$ & $0.232^{* *}$ & $0.313^{* *}$ & $0.466^{* *}$ & \\
BL & $0.463^{* *}$ & $0.406^{* *}$ & $0.328^{* *}$ & $0.411^{* *}$ & $0.508^{* *}$ & $0.403^{* *}$ \\
\hline
\end{tabular}

Note: $* p<0.05 ;$

\subsection{Regression analysis}

The linear regression equation represents the relationship among six determinants (independent variables) and the brand loyalty of customers in organic industry in Vietnam (dependent variable).

Table 4 in the output, shown below, includes information about the quantity of variance that is explained by predictor variables. The first value, $\mathrm{R}$ Square, is simply the squared value of $\mathrm{R}$. This is frequently used to describe the goodness-of-fit or the amount of variance explained by a given set of predictor variables. The value of $R$ 


\section{Nguyen Cuong Nam}

Square is 0.535 , which indicates that $53.5 \%$ of the variance in the dependent variable is explained by the independent variables in the model.Besides, the Durbin-Watson coefficient is 1.739 , which means that there is no autocorrelation detected in this model.The $\mathrm{F}$ statistic represents a test of the null hypothesis that the expected values of the regression coefficients are equal to each other and that they equal zero. Put another way, this $\mathrm{F}$ statistic tests whether the $\mathrm{R}$ square proportion of variance in the dependent variable accounted for by the predictors is zero. If the null hypothesis were true, then that would indicate that there is not a regression relationship between the dependent variable and the predictor variables. But, instead, it appears that the six predictor variables are not all equal to each other and could be used to predict the dependent variable, BL (Brand Loyalty), as is indicated by a large $\mathrm{F}$ value $=65.915$ and a small significance level ( $\mathrm{Sig}=0.000$ ).According to the result of VIF coefficients of all independent variables, we can see that all of them are less than 2 . This result reveals that the problem of multicolinearity does not exist in this regression model. Therefore, this model formulation is acceptable and can be proceed.

Additionally, in model 1-7, which indicate respectively linear regression relationship between different independent variables and dependent variable, for example, the model 1 reprents the linear regression relationship between functional value and brand loyalty. Sig. value of all components, including FV, SV, EV, PW, BT and BSRI are all less than 0.05. It demonstrates that there is not any variable rejected from this model; and all these independent variables are significant to explain for dependent variable (BL). The above regression results demonstrate that the hypothesis of $\mathrm{H} 1, \mathrm{H} 2, \mathrm{H} 3, \mathrm{H} 4, \mathrm{H} 5$, and $\mathrm{H} 6$ are supported by empirical data.

Table 4: Regression result

\begin{tabular}{|c|c|c|c|c|c|c|c|}
\hline & \multicolumn{6}{|c|}{ Dependent Variable: Brand Loyalty (BL) } & \multirow[b]{2}{*}{ VIF } \\
\hline & $\begin{array}{c}\text { Model } \\
1\end{array}$ & $\begin{array}{c}\text { Model } \\
2\end{array}$ & $\begin{array}{c}\text { Model } \\
\mathbf{3}\end{array}$ & $\begin{array}{c}\text { Model } \\
4\end{array}$ & $\begin{array}{c}\text { Model } \\
5\end{array}$ & $\begin{array}{c}\text { Model } \\
6\end{array}$ & \\
\hline FV & $0.251^{* * *}$ & & & & & & 1.232 \\
\hline SV & & $0.171^{\text {**** }}$ & & & & & 1.122 \\
\hline $\mathrm{EV}$ & & & $0.166^{* * *}$ & & & & 1.268 \\
\hline PW & & & & $0.181^{* *}$ & & & 1.584 \\
\hline BT & & & & & $0.299^{* *}$ & & 1.362 \\
\hline BSRI & & & & & & $0.135^{*}$ & 1.313 \\
\hline$R^{2}$ & & & 0.53 & & & & \\
\hline Durbin-Watson & & & 1.73 & & & & \\
\hline$F$ Value & & & 65.915 & *** & & & \\
\hline
\end{tabular}

\subsection{Results of hypothesis}

Table 5: Summary result of hypothesis test

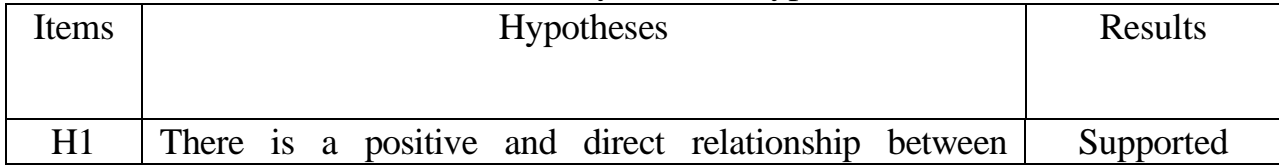


Research on Determinants of Brand Loyalty of Consumer: Evidence from Organic Food Industry in Vietnam

\begin{tabular}{|c|l|c|}
\hline & functional value and brand loyalty. & \\
\hline H2 & $\begin{array}{l}\text { There is a positive and direct relationship between } \\
\text { emotional value and brand loyalty. }\end{array}$ & Supported \\
\hline H3 & $\begin{array}{l}\text { There is a positive and direct relationship between social } \\
\text { value and brand loyalty. }\end{array}$ & Supported \\
\hline H4 & $\begin{array}{l}\text { There is a positive and direct relationship between price } \\
\text { worthiness and brand loyalty. }\end{array}$ & Supported \\
\hline H5 & $\begin{array}{l}\text { There is a positive and direct relationship between brand } \\
\text { trust and brand loyalty. }\end{array}$ & Supported \\
\hline H6 & $\begin{array}{l}\text { There is a positive and direct relationship between brand } \\
\text { social responsibility and brand loyalty. }\end{array}$ & Supported \\
\hline
\end{tabular}

\section{Conclusion}

According to the research results, six independent variables, including Functional Value (FV); Social Value (SV); Emotional Value (EV); Price Worthiness (PW); Brand Trust (BT) and Brand Social Responsibility Image (BSRI) totally influence on the dependent variable Brand Loyalty (BL). As a result, this research gained insights into organic industry in Vietnam's marketing strategies with several findings as follows.

Based on the Standardized Coefficients of Beta, the order from strongest to lowest influencing level of independent variables to dependent variable (BL) is: FV $(0.225)>\mathrm{BT}(0.213)>\mathrm{SV}(0.163)>\mathrm{PW}(0.149)>\mathrm{EV}(0.148)$ and BSRI (0.114), which means that factor Functional Value is the greatest factor influencing on brand loyalty of consumer on organic food industry in Vietnam; follow by Brand Trust; Social Value; Price Worthiness; Emotional Value and Brand Social Responsibility Image. In other word, to maintain and enhance the brand loyalty of consumer, especially in organic food industry, Vietnamese companies doing business in manufacturing and purchasing the organic products have to come up with the solutions as well as the marketing strategies to both attract customers and maintain stable numbers of loyal customer by promotion the perceived value of customer about functional value; social value; emotional value and price worthiness. Besides, the companies also need to spread their social responsibility image of their brand to the customer, and the most significant factor is brand trust of customers by enhancement their awareness about the high quality, benefits and the perceived value affecting on their health and environment of the organic products.

\subsection{Recommendations}

In order to build and maintain the brand loyalty of Vietnamese consumer to organic products, it is extremely significant to Vietnamese enterprises to research and analyze the influencing factors such as perceived values, especially functional value; social value; emotional value and price worthiness of the products; customer satisfaction; brand trust, customer involvement as well as brand social responsibility image.

Firstly, the quality of products plays the most crucial role in building the brand loyalty of customer, which is mainly due to the fact that the better the quality of 


\section{Nguyen Cuong Nam}

products is, the higher degree of brand trust of customers is. In addition, the enterprises need to be honest and intelligible to their customers by maintaining the reputation of their business, listening and respecting the psychology, purchasing habit and benefits of customers... More importantly, the companies should come up with the discount programs, promotions or organizing the activities of trying new products freely in some special occasions or events such as Black Friday; big sale 11-11; Tet Holiday; Christmas... This attracts more attentions of customers to their products as well as expanding their brands on the organic market, which promotes customer's brand trust.

In terms of functional value of product, business manufacturing the organic products needs to note that they have to make sure about the real quality and the outstanding advantages as well as the positive effects of organic products on their health, their beauty... comparing with normal products. More importantly, the companies need to show the customers that their products are tested and approved by the standard quality verification system for organic products by printing verification stamp or label attaching with the products. Besides, the store or supermarkets selling organic products have to make sure that their products are real organic food by achieving the certificate of standard quality verification system for organic products to express their business ethics which is really important in the cuisine industry, especially organic food.

Additionally, price worthiness is one of the most important factors that influencing on the brand loyalty of consumers. Pricing based on the degree of perceived value of customer is the most effective method. The higher degree of perceived value that customers can find when using the organic food is, the higher level of brand loyalty of customer is. If they find the quality of the products brought to them, they will be sure to spend their money to buy these products. For organic products with high quality, the price stability should be considering by the companies; because this research's results, once the customers find the price worthiness with the quality of products, their degree of brand loyalty will increase soarly. Furthermore, decreasing the price which is lower than other products' price on the market is not an efficient way for companies to enhance the degree of brand loyalty of consumer; because this will negative affect on their psychology of thinking about the real quality of the products.

To express or boost the brand social responsibility image, the organic companies should use a small part of their benefits to organize the charity to difficult area in Vietnam to show their social responsibility, how they contribute to society. Besides, these companies also should hold the workshops or conferences to talk about the benefits of organic to environment and community healthcare, which raises awareness as well as the brand trust to consumers who have purchased and used organic food products. More importantly, organic companies should build and develop the organic farming experiences for consumer. Consumer can come and grow vegetables by themselves, which helps them understand the differences between normal food and organic food, they therefore raise and maintain their brand trust and satisfaction when experiencing in organic farm, do what they eat every day and aware of their real benefits to their health and community including environmental issue and healthcare. 
Research on Determinants of Brand Loyalty of Consumer: Evidence from Organic Food Industry in Vietnam

When establishing the distribution channel, there are three crucial tasks that the company has to note, including making the products appear on the market; making consumer realize their products and turning the selling places into the place to advertise the products.

For the first task of the distribution channel - making the product appear on the market, which means that the company has to make the product available for customers to buy wherever they want. Besides, the enterprises must identify their potential markets, which helps them promptly supplying products to customers. Once the products of the business are available in potential markets, with wide coverage, creating commitment for customers, it is certain that consumers will not hesitate to purchase and use the products of the business.

\subsection{Suggestion for the future research}

To improve the research scopes, the author suggested that the further research should extent the research scopes by conducting the survey and collecting the data from consumer in small cities or different areas in Vietnam to explore other factors influencing on brand loyalty of consumer on organic food industry as well as explore the potential and loyal customer of this kind of product.

The concept model of determinants of brand loyalty of consumers need to estimate and conduct when researching for various types of organic products in the various context of different market.

\section{REFERENCES}

1. V.L.Hunter, Measure customer loyalty for complete picture of ROI, Business Marketing, 83 (8) (1998) 18.

2. D.A.Aaker, Consumers true brand loyalty: The central role of commitment, Journal of Strategic Marketing, 6 (1991) 305 - 319.

3. A. I.Moolla and C.A.Bisschoff, A Model to Measure the Brand Loyalty for Fast Moving Consumer Goods, Journal of Social Science, 31 (2012) 71-85.

4. A.Amine, Consumers true brand loyalty: The central role of consumer involvement, Journal of Strategic Marketing, 6 (1998) 305 - 319.

5. H.Assel, Consumer Behavior and Marketing Action, Fourth Edition, PWS-KENT Publishing Company (1992).

6. R.E.Baloglu and S.Siddarth, Determining Segmentation in Sales Response Across Consumer Purchase Behaviors, Journal of Marketing Research, 35 (2002) 189-198.

7. R.Bennett and S.Rundle-Thiele, A comparison of attitudinal loyalty measurement approaches, Journal of Brand Management, 9(3) (2002) 193-209.

8. G.H.Brown, Brand Loyalty - Fact or Fiction?, Advertising Age, 23 (1952) 53-55.

9. A.Caruana and N.Fenech, The effect of perceived value and overall satisfaction on loyalty: A study among dental patients, Journal of Medical Marketing, 5 (2005) 245-255. 


\section{Nguyen Cuong Nam}

10. A.S.Dick and K.Basu, Customer loyalty: Toward an integrated conceptual framework, Journal of the Academy of Marketing Science, 22(2) (1994) 99-113.

11. Dinh Thi Tra Nhi, Establishing and developing the brand of tourism in Danang City. University of Social Sciences and Humanities (2010).

12. Do Thi Ngoc Anh, Establishing and protecting the brand of Vietnamese commodity, Journal of Social Sciences and Humanities, 54(2) (2006) 61-67.

13. D.C.Funk and J.D.James, The psychological continuum model: A conceptual framework for understanding an individual's psychological connection to sport, Sport Management Review, 4 (2001) 119-150.

14. Garbarino and Johnson, The Effects of Brand Experiences, Trust and Satisfaction on Building Brand Loyalty: An Empirical Research on Global Brands, Journal of Social and Behavioral Sciences, 24 (1991) 1288-1301.

15. S.Gounaris and V.Stathakopoulos, Antecedents and consequences of brand loyalty: An empirical study, Journal of Brand Management, 11(4) (2004) 283.

16. B.K.Huynh Trung, What is the definition of organic and their benefits? Journal of The Organic Fresh Food Emporium, 7(2) (2018) 35-44.

17. W.Jacoby and R.Chestnut, Brand Loyalty: measurement and management, John Wiley and Sons, New York (1978).

18. T.O.Jones and W.E.Sasser, Why satisfied customers defect?, Havard Business Review, 73 (2007) 88-99.

19. Kim, Ki-Joon Back and S.C.Parks, A brand loyalty model involving cognitive, affective, and conative brand loyalty and customer satisfaction, Journal of Hospitality \& Tourism Research, 27(4) (2004) 419-435.

20. P.Kotler and Keller, Marketing Management, Millenium Edition, Prentice Hall Inc., New Jersey (2012).

21. Lin et al., Risk and perceived value: Antecedents of customer satisfaction and loyalty in a sustainable business model, Economic Research, 32 (2006) 909-924.

22. Luc Bui Anh Dung, Brand value of mobile network Vinaphone in Vietnamese market. Journal of University of Posts and Telecommunications Institute of Technology, 64(2) (2010) 23-27.

23. Nguyen Thu Ha, Establishing and developing the brand of Vietnamese tea in the context of international economic integration, Scientific research, University of Economics - Vietnam National University (2011).

24. L.R.Oliver, Cognitive, affective, and attribute bases of the satisfaction response, Journal of Consumer Research, 20 (1999) 418-430.

25. B.Olsen, Brand loyalty and consumption patterns, the lineage factor, in contemporary marketing and consumer behaviour, Journal of Consumer Research, (1997) 245-278

26. Poolthong and Mandhachitara, A model of customer loyalty and corporate social responsibility, Journal of Services Marketing, 25(2) (2011) 122-133.

27. M.Punniyamoorthy and M.Raj, An empirical model for brand loyalty measurement, Journal of Targeting, Measurement and Analysis for Marketing, 15 (2007) 222-233.

28. F.F.Reichheld, Learning from customer defections, Harvard Business Review, 74 (1996) 56-67. 
Research on Determinants of Brand Loyalty of Consumer: Evidence from Organic Food Industry in Vietnam

29. S.Rundle-Thiele and R.Bennett, A brand for all seasons? Adiscussion of brand loyalty approaches and their applicability for different markets, Journal of Product and Brand Management, 10(1) (2001) 25-37.

30. Ryan et al., M.Uncles and G.Dowling, Consumer Loyalty Marketing in Repeatpurchase Markets, University of New South Wales, Sydney, Australia (1999).

31. R.Sekar, H.R.Unnava and N.V.Montgomery, The moderating effect of brand commitment on the evaluation of competitive brands, Journal of Advertising, 38 (2009) 21-35.

32. T.Weiwei, Impact of corporate image and corporate reputation on customer loyalty: A review, Management Science and Engineering, 1 (2007) 57-62.

33. M.Uncles and G.Dowling, Consumer Loyalty Marketing in Repeat- purchase Markets, University of New South Wales, Sydney, Australia (1998). 